\title{
Feast AND Famine: A Statewide Science Serial Collection Assessment in Illinois
}

\author{
Tina E. Chrzastowski, Chew Chiat Naun, Michael \\ Norman, and Karen Schmidt
}

In 2004, a group of Illinois librarians was awarded a research grant to assess the state of Illinois' science serial collection. This collection assessment focused on academic libraries in the state, specifically those participating in the Consortium of Academic Research Libraries in Illinois (CARLI), but also including another 10 academic libraries in the state that do not belong to the consortium. Current serial subscription data were collected through both automated and manual means and the analysis was conducted in conjunction with Ulrich's Serials Analysis System. Due to cataloging limitations and issues surrounding different ISSNs for print and electronic formats, the study centered on current (as of spring 2005) print serial subscriptions. Results found that well over half of the state's print serial subscriptions were Illinois' "last copy" and another 13 percent were at risk, with only two copies owned in the state. And while most titles were limited to one print copy within Illinois, other titles have wide accessibility and duplication at a high cost to the state.

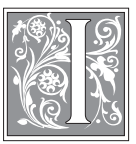

llinois libraries invest millions of dollars annually in the subscription and maintenance of science serials. This investment and commitment involves and affects every library in the state, making the study of this collection a critical undertaking. New tools have made the assessment of these collections easier, allowing librarians to gather and analyze data on how our collections are similar and different and how they function as a statewide collection to serve our users.

This study of current serial subscriptions looks at broad subject coverage within the sciences. It follows monographic collection assessments already done in Illinois, both with an earlier collection overlap study conducted by Potter ${ }^{1}$ and more recently by Munroe. ${ }^{2}$ Both of these studies, though separated by a span of 20 years, reflect the diversity that is seen in academic library

Tina E. Chrzastowski is Chemistry Librarian, University of Illinois at Urbana-Champaign (UIUC); Chiat Naun Chew is Principal Cataloger, University of Minnesota Libraries, formerly Senior Coordinating Cataloger, UIUC; Michael Norman is Head, Content Access Management, UIUC; Karen Schmidt is University Librarian, Illinois Wesleyan University, formerly Associate University Librarian for Collections, UIUC; e-mail: chrz@uiuc.edu, chewx006@umn.edu,manorman@uiuc.edu, and karens@iwu.edu. The authors gratefully acknowledge the financial support of CARLI, the Consortium of Academic and Research Libraries in Illinois, and wish to especially thank graduate assistants Esra Coskun and Jacquelyn Erdman for their hours of work searching serial titles. 
collections regardless of size and point to the interdependency of libraries in providing a rich array of resources for students, researchers and citizens in the state.

Illinois libraries have enjoyed a long history of resource sharing and analysis. From the mid-1970s, the state has worked on a number of cooperative collection development initiatives and has provided funding for joint acquisitions. This study grew from a discussion among Illinois science librarians searching for opportunities to provide shared access to online science journals. It sought to answer the following questions: "How can we better understand the statewide consequences of canceling print subscriptions?" "How many current subscriptions are duplicated among science libraries?" and "What sorts of print cancellation decisions are libraries making that endanger our longterm access to content?"

Libraries now have the data and tools necessary to answer these questions. Through a grant from the Consortium of Academic Research Libraries in Illinois (CARLI) (formerly granted by the Illinois Cooperative Collection Management Program), the authors were able to acquire short-term access to the Ulrich's Serials Analysis System and use it to examine current science serial subscriptions in Illinois academic libraries. Two of the investigators on this project had previously critiqued the Ulrich's product and fully understood its capabilities and limitations, thus aiding in the design of the study. ${ }^{3}$ The purpose of the study was twofold: 1) to understand and describe both the overlapping and unique current science serial collections in the state; and 2) to lay the groundwork for building a collaborative approach to acquiring access to digital content for the titles that are the most commonly held.

The year 2005 may not seem the most opportune time to conduct a study of print serial subscriptions. Many print subscriptions have been cancelled in Illinois in recent years due to the availability of electronic access to full-text journal articles. It is expected that, if this study had been conducted even a few years earlier, more print subscriptions and a greater overlap of holdings would have been found. However, creating a baseline of print subscriptions in 2005 is still useful and, in fact, seizes on a moment of significance to libraries in fulfilling responsibilities of preservation and stewardship. It is critical to find and identify that "last copy" in the state in order to make informed decisions about its fate. It is also useful to have an idea of where the greatest overlap is taking place and therefore where the greatest overlap of funds is being expended. The data analysis demonstrated that this type of study, even with its limitations, is well worth the effort.

\section{Previous Research}

The literature on collection overlap covers many years and reflects many types of methodologies and collection needs and outcomes. As union catalogs became an established tool, studies of the effect of multiple holdings in library collections grew. Illinois' own Robert Downs established a cornerstone study in 1942 in a set of essays on union catalogs in the United States. ${ }^{4}$ Interest in collection overlap studies intensified in the 1970s, when funding for higher education and libraries began to tighten, and they have continued at a fairly frequent rate throughout the 1980s and 1990s and into the present decade. Examples include Strubbe's 1989 study of overlap within a single academic library, ${ }^{5}$ the 1997 study of serial overlap in Glasgow area academic libraries, ${ }^{6}$ Zainib and $\mathrm{Ng}^{\prime}$ ' research on availability and overlap in computer science journals, ${ }^{7}$ and more recently Metz and Gasser's serial overlap study for the Virtual Library of Virginia (VIVA). ${ }^{8}$

Strubbe's research reflects the publishing era just before the rise of electronic journals and demonstrates the careful analysis that academic libraries usually undertake in avoiding all but the most critical of print duplication. The Glasgow 
study cites many of the challenges in conducting journal overlap studies, including the lack of ISSNs and, again, the need to duplicate print subscriptions in critical areas of study. And, reflecting the growing availability of electronic journals, the Zainib \& $\mathrm{Ng}$ research examines the opportunities of a cooperative set of print subscriptions that collectively might allow access to the wider possible array of journals, both print and electronic. Metz and Gasser employ the Ulrich's Serials Analysis System to evaluate both print and online serial overlap in Virginia.

In general, the literature of collection overlap echoes the growing sophistication of tools at our disposal for understanding our collections and making informed and rational decisions for duplication, unique holdings, and resource sharing. Perhaps the biggest challenge to the studies remains the lack of specific information and the potential for mismatching of titles. Nevertheless, the tools and the holdings records they analyze continue to be critical to our informed decision making and the future landscape of our collections.

The literature on statewide or multiplelibrary, consortium collection assessments is a much smaller but growing group of articles, recently focusing on consortially held journals, as this study does. For example, Shottlaender ${ }^{9}$ and others studied a sample of the journal collection of the University of California Libraries that was simultaneously available in print and electronic format and in libraries where print was available and in libraries where print was in storage. The journal-use study portion of this research found that electronic journals were used as much as 16:1 over print where print was available on site. Very little comment was registered when print was completely removed to remote storage and only electronic journal access was made available. Davis ${ }^{10}$ analyzed 2000 and 2001 electronic journal use data (from Academic Press' IDEAL package of journals) from the NorthEast Research Library (NERL) consortium. One of the findings of Davis' study was that cluster analysis clearly defined three distinct types of use based on institution type: large research libraries, medical libraries, and smaller liberal arts and polytechnic libraries. Finally, Sanville ${ }^{11}$ studied OhioLINK electronic journal use data over a three-year period and found great benefits to all OhioLINK libraries, but particularly noted that access to articles not available in print and only available online through OhioLINK was highly significant, noting "new access represented over two-thirds of the titles downloaded for all but the two largest libraries in the state." These consortium-based research articles show the positives possible when moving shared print collections to online access or providing new online access to a wide group of related libraries.

\section{Hypotheses}

Hypotheses provide the basis for questioning and illuminating collected data. A number of hypotheses were posed by the authors to design database queries and the data analysis. The following predictions were made for this study of Illinois' current print science serial collection.

- An estimated one-third of all serial titles will be "last copy" titles, held by only one library in the state.

- Ten percent of titles will be "nextto-last" copies, held by only two libraries in Illinois.

- The single-subject call number class with the most print titles will be LC call number range QA (math). This hypothesis is based on our observation that mathematics is a science-based discipline that continues to value print subscriptions highly.

- Most unique titles will be currently owned by the largest research libraries in the state, those serving an FTE student population over 20,000.

- Cost matters; the higher the cost of a journal, the fewer number of copies that will be currently owned.

- Disciplines with the highest percentage of online journal availability will be chemistry and physics. This hypothesis is 
based on our observation that both chemistry and physics were early adopters to digital content, and researchers and students in these disciplines are avid users.

- The most expensive journals by call number will be Chemistry (QD). This assumption is based on serial price increase data, which continually ranks chemistry as one of the most expensive disciplines.

- The total cost of current print science serial subscriptions in Illinois will exceed 10 million dollars per year.

- Over 80 percent of currently received, nongift print science serial titles will be available online.

\section{Methodology}

Data collection and analyses were divided into three distinct components. First, a union list of currently owned science serials was built from the 65 CARLI libraries' Voyager Universal Catalog records and data from another ten contributing libraries that provided records of their current science serial holdings. This union list was then matched against Ulrich's Serials Analysis System database to gather additional information about a serial title, including list price, publisher, both Dewey and LC call numbers, electronic availability, peer-reviewed status, indexing and Ulrich subject category. Finally, the enhanced database was analyzed to answer questions posed by the hypotheses. Naturally, actual events in this threestep process were hampered by realities that are to be expected when dealing with large numbers of serials and bibliographic records from 75 libraries. These "realities" will be addressed later in this paper.

The primary source for creating a database of every current, print science serial owned in Illinois was the Voyager Universal Catalog. This union catalog is shared by 65 academic libraries in Illinois and provided an established consortia database to gather current serial subscription information. Other academic libraries in the state were invited and encouraged to participate in this study. This resulted in another ten libraries joining the study by contributing current, print science serial subscription information. The academic libraries making up the study cover the spectrum of sizes ranging from very large research libraries (for example, the University of Chicago and the University of Illinois at Urbana-Champaign [UIUC]), medium-sized libraries (for example, Illinois Wesleyan and DePaul University) and smaller academic libraries (for example, Augustana College and Columbia College). (A complete list of the 75 participating libraries is found in Appendix A.) Because the purpose of the study was to look at the statewide collection, no individual library's complete collection of science serial subscriptions is identified. Small snippets of data may identify some library subscriptions, but only to show pieces of the database or to illustrate other methodological steps. Offering general anonymity to participating libraries made it easier to gain permission to use library data. In addition to granting permission to access or receive a library's science serial subscription data, every participating library received a spreadsheet showing their holdings from the database, which included all information gathered by the study and from Ulrich's. In addition, each library's "last copy" and "next-to-last copy" titles were identified.

A "science serial" was defined very broadly for this study to create a panoramic view of Illinois' collections. Initial queries to the Voyager Universal Catalog defined science serials by their call number classification. The subjects included in the study covered core areas such as biology, chemistry, physics, and geology but also extended to areas such as mathematics, agriculture, health sciences, technology, and engineering. "Serial" was also defined broadly, using CONSER's definition: "a publication in any medium issued in successive parts bearing numeric or chronological designations and intended to be indefinitely." ${ }^{12}$ Table 1 shows the call number ranges used in the database queries to identify current science serial subscriptions. 


\begin{tabular}{|c|c|}
\hline \multicolumn{2}{|c|}{$\begin{array}{c}\text { TABLE } 1 \\
\text { Dewey, Library of Congress and } \\
\text { National Library of Medicine (NLM) } \\
\text { Call Numbers Used for this Study } \\
\end{array}$} \\
\hline $\begin{array}{l}\text { Dewey Call } \\
\text { Numbers }\end{array}$ & $\begin{array}{l}\text { Library of Congress and } \\
\text { NLM Call Numbers }\end{array}$ \\
\hline 004-006 & Class codes Q-TZ \\
\hline $150-159$ & Class code BF \\
\hline $500-599$ & Class code ZA \\
\hline $600-649$ & Class codes W-WZ \\
\hline $660-699$ & $\begin{array}{l}\text { Miscellaneous Classes (from } \\
\text { titles contributed in lists) }\end{array}$ \\
\hline
\end{tabular}

While it seems simple to query a union catalog to cull current science serial subscriptions, a number of different tactics were employed to thoroughly capture every eligible title. The query "record type $=a$; bib level $=s^{\prime \prime}$ with a purchase order for the current fiscal year and in the specified call number ranges brought in many needed titles. A second query, "record type=a; bib level $=\mathrm{s}$; items created since $1 / 1 / 04$ " in the specified call number ranges, pulled in those titles without purchase orders but with recently created item records. These two queries should have found most of the current science serials for the libraries using the Voyager Universal Catalog. However, some libraries do not classify their serials, add item records to their serial bibliographic records, or use Voyager to record current purchase orders. To pull the needed data from these libraries, all their serial titles were identified and reviewed manually in their OPACS to determine current subscriptions to science serials.

The final 75-library union list of current, print science serial subscriptions was compiled by merging data from Voyager and hand-created lists. For the most part, this merging of data occurred without any problem. However, difficulties arose if there was any variation in title or ISSN (International Standard Serial Number), if no ISSN was available, if no OCLC number was available, or if different bibliographic records were created within the Voyager Universal Catalog for the same title. Over 100 hours were spent cleaning up and merging the two data sets (Voyager and non-Voyager libraries) to ensure that correct serial titles, ISSNs, and OCLC numbers accurately matched throughout the union list. This careful review was done for a total of 14,098 individual serial titles, representing 35,932 holdings of these print science serials.

Figure 1 shows a sample of the database (or union list) with UIUC titles. The far left column shows the OCLC symbol (uiu), followed by title, three columns for ISSN, and the OCLC number. The three ISSN columns represent the three subfields where ISSN might be stored in the OCLC record. The data shown in figure 1 provided the basis for the database and each participating library's data were stored in a separate file.

The second phase of data analysis involved the use of the Ulrich's Serial Analysis System (USAS). The grant supporting this research provided funds to contract with Ulrich's for access to their "universal" database. Access was acquired for an initial four-week time period; Ulrich's subsequently agreed to extend the period of access when further work proved to be necessary, and they also provided system training. USAS added value to the database by providing additional information about each serial title included in the data set, including price, call numbers, electronic availability, peer-reviewed status, and ISI Impact factor. A sample section of the database with the data from USAS is found in figure 2 .

To utilize the Ulrich's database, a plain-text tab delimited file of ISSNs corresponding to serial titles held in the institution's collection was uploaded to Ulrich's. Ulrich's Serials Analysis System performed fairly well in matching current ISSNs and alternate ISSNs (electronic, incorrect, previous title). This process created a database of these titles, separately (by library) and also as a conglomerate 


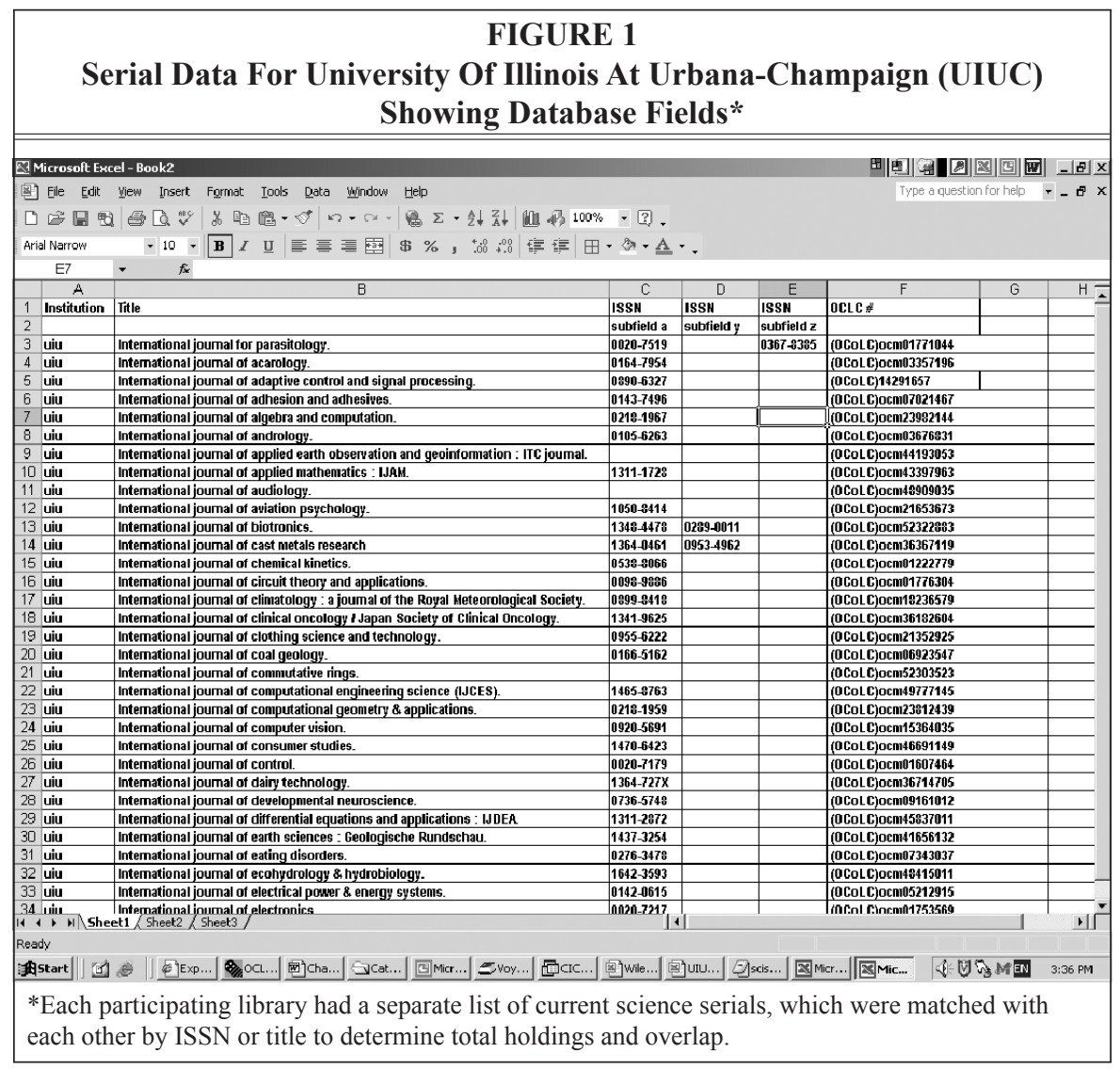

(Ulrich's "Consortium Universe"). The USAS created an audit report highlighting invalid ISSNs, duplicate titles, and other problems with matching. Once problems were identified, cleanup work began to fix invalid or incorrect ISSNs and duplicate titles. Obviously, a project of this size required a great deal of cleanup totaling months of work. Many titles did not have an initial match point within Ulrich's; most of these did not have an ISSN within our database. Out of 14,098 individual titles comprising the union list of science serials, the USAS matched 8,478 titles, about 60 percent. This was a much lower percentage than was expected, and extended the work plan due to the need for still more database cleanup.

Several hundred of these unmatched titles were due to errors with the data collected from the Voyager Universal
Catalog such as incorrect ISSNs, missed title changes, and titles that had ceased or been retired. The reality is that consortium libraries have not been diligently upgrading records and making serial title changes. In addition, many of the titles did not have an ISSN within the bibliographic records populating our online catalogs. Either there was an existing ISSN and it was not included in cataloging, or these titles had never been assigned an ISSN. It was discovered that many of these titles are included within Ulrich's system as found in ulrichsweb.com [www.ulrichsweb. com] although they do not appear in the USAS. In these cases, the titles had to be matched manually, with ISSNs collected where available.

Many of the nonmatches were foreign language science titles. Because of the varying cataloging treatment of these 
titles, it is extremely difficult to match by title for these serials, especially Asianlanguage and Slavic-language titles. For these titles, careful reviewing located some duplicates; but because of the nature of these titles, many were considered to be the only copy owned by one library in the state.

USAS worked well when an ISSN was available for matching. The data most useful to this study provided by Ulrich's included list price, publisher, electronic availability, peer-reviewed status, subject category, and ISSN. The data we would have liked to acquire (and which are available through other Ulrich's products) included alternate edition ISSNs, frequency, start year of publication, all prices associated with title (including non-U.S. dollar prices), CODEN, URL, where the title is indexed/abstracted, publisher contact information, and the Ulrich's internal number for a serial title. These data would have enriched the database and provided important other evaluation and comparison points for each title.

While a product such as USAS was essential with serial identification issues, and provided the study with numerous additional descriptive fields for each title, database software (such as Microsoft Excel and Microsoft Access) turned out to be our most useful tools, well-supported by local serials data, union catalogs, and OCLC. Because this study focused on current print science serial subscriptions in Illinois, other features offered by USAS, such as comparing holdings to the Ulrich's "Universe" (189,000 active titles) or to Ulrich's "Core" (50,000 academic and scholarly journals titles), were determined to be secondary to this initial study. These types of comparisons were reviewed by VIVA, The Virtual Library of Virginia, and are reported by Metz and Gasser ${ }^{13}$.

Even after further title research and cleanup, approximately 3,684 titles (or about 26 percent) could not be identified

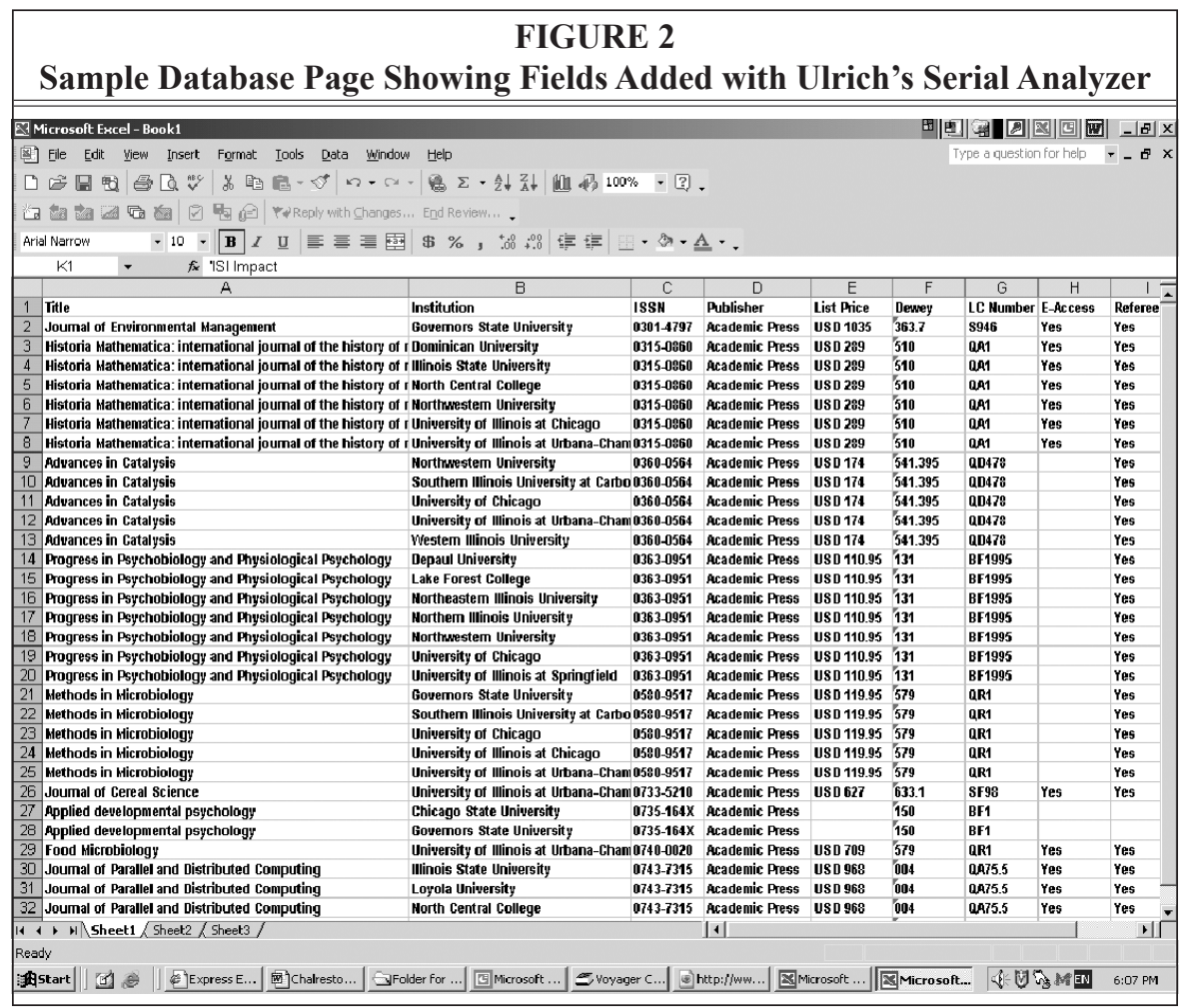




\begin{tabular}{|c|c|c|}
\hline \multicolumn{3}{|c|}{ TABLE 2 } \\
$\begin{array}{c}\text { Frequency Distribution of Print Science } \\
\text { Serial Subscriptions in Illinois, Spring 2005, } \\
\text { by Number of Subscribers }\end{array}$ \\
\hline \hline $\begin{array}{c}\text { Number of } \\
\text { Subscribing Libraries }\end{array}$ & $\begin{array}{c}\text { Number } \\
\text { of Titles }\end{array}$ & $\begin{array}{c}\text { Cumulative Total, } \\
\text { Subscribed titles }\end{array}$ \\
\hline 1 & 8,307 & 8,307 \\
\hline 2 & 1,972 & 10,279 \\
\hline 3 & 1,127 & 11,406 \\
\hline 4 & 463 & 11,869 \\
\hline $5-9$ & 1,474 & 13,343 \\
\hline $10-19$ & 603 & 13,946 \\
\hline More than 20 & 152 & 14,098 \\
\hline Total & 14,098 & 14,098 \\
\hline
\end{tabular}

print science serial collection is unique - a single current print subscription in Illinois. This percentage exceeds the 33 percent predicted by the authors and therefore this hypothesis was not proven.

The study also found that there are 1,972 titles "at risk" - those serials currently owned in print by only two libraries in Illinois. This is another 14 percent of titles and slightly exceeds the prediction of the second hypothesis,

in Ulrich's database by any means. This is likely to happen in large consortium databases in which holdings will include obscure or rarely held serial titles that could include, for example, foreign language or gift titles. However, the importance of accurate and current serial records cannot be overstated-especially when it comes to conducting collection assessment.

\section{Results}

As of spring 2005, there were 35,932 print science serial subscriptions (including duplicate copies) in Illinois. These subscriptions are made up of 14,098 individual current serial titles. As shown in table 2, a frequency distribution of titles owned by number of subscribing libraries, of the 14,098 titles, 8,307 are held in print by only one library. Therefore 59 percent of Illinois' which stated that another 10 percent of titles would be "next-to-last" copies, owned by only two libraries in Illinois. In all, 10,279 serial titles are currently subscribed to by only one or two libraries, meaning that 73 percent of all print science serial titles in Illinois are now, or have the immediate potential to be, the last print copy owned in the state.

Figure 3 shows the distribution of print science serials currently subscribed to in Illinois by call number. The fourth hypothesis predicted that the single-subject call number class with the most print titles would be LC call number range QA (math). Figure 3 confirms this hypothesis, which was based on sheer volumes of titles and the observation that math titles are not only numerous but are in

\begin{tabular}{|l|c|}
\hline \multicolumn{2}{|c|}{ TABLE 3 } \\
\hline \hline Libraries with the Largest Numbers of Unique Titles* \\
\hline \hline Institution & $\begin{array}{c}\text { Number of Unique Science } \\
\text { Print Journal Titles Held }\end{array}$ \\
\hline University of Illinois at Urbana-Champaign & 3,466 \\
\hline Research Library X (FTE Student $>20,000)$ & 2,305 \\
\hline Research Library Y (FTE Student $>20,000)$ & 560 \\
\hline $\begin{array}{l}\text { *The data from this table support the hypothesis that larger institutions have more unique titles. How- } \\
\text { ever, even smaller libraries are contributing unique holdings to the state-wide collection, with } 77 \% \text { of } \\
\text { all libraries owning at least one unique current subscription. }\end{array}$ \\
\hline
\end{tabular}




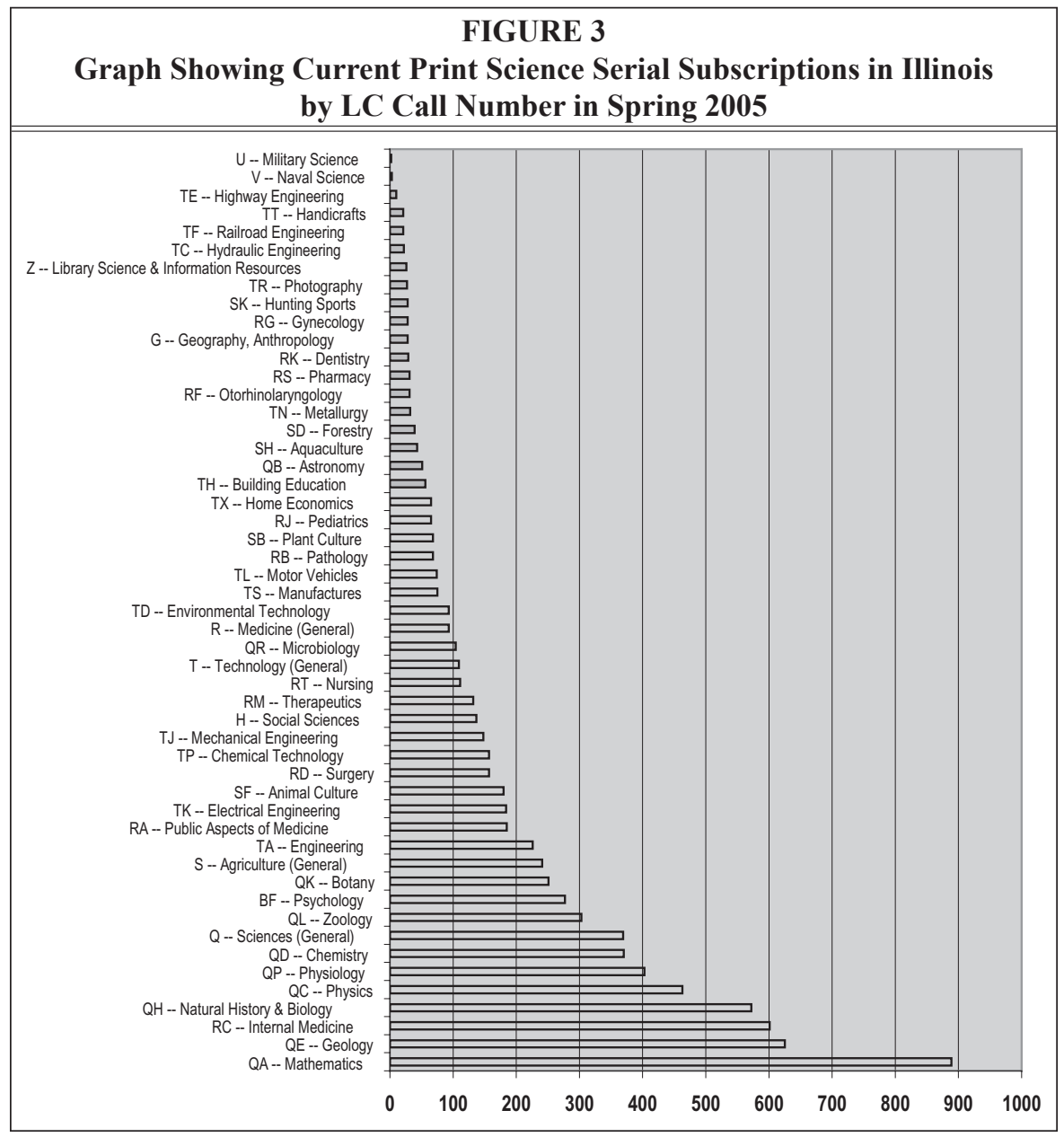

a subject field with surprisingly few online titles and with scholars who, at least until recently, prefer print. Another view of this hypothesis would be to review the number of copies owned per title by discipline, as is found in table 5 . With this view, BF (Psychology) has the highest number of copies per title in the state. It is important to note that other science fields may have taken opportunities recently to move to electronic-only subscriptions based on patron preferences or budgetary constraints and that this distribution of current subscriptions by call number is valid only for spring 2005.

As was predicted, and as shown in table 3, the largest libraries in the state (ranked by FTE student populations) subscribe to the most unique titles. Table 3 shows that the state's largest academic library, the University of Illinois at Urbana-Champaign (UIUC), currently receives the most unique titles, followed by two other large research libraries in the state. Libraries are not identified by name to preserve confidentiality of their subscription data. Data from table 3 confirm the fourth hypothesis, which states that most of the unique titles will be currently owned by the largest research libraries in the state, those with an FTE student population over 20,000. One important finding is that fifty-eight of the seventy-five libraries in the study, or 
77 percent, currently subscribe to at least one unique title for the state. Illinois' collections are very much dependent on each other to maintain diverse collections and support regional interests. Every library counts.

The fifth hypothesis predicted that "cost matters," and that the higher the cost of a journal title, the less likely it was to be currently owned in the state. Table 4 shows the number and cost of print science serials in Illinois grouped by broad price range. As predicted, the higher priced journals are less widely owned, having a copy/title ratio of 2.29 , below the average in the overall study of 2.55 and the lowest of those titles for which cost could be determined. Table 4 also addresses the hypothesis concerning total expenditures in Illinois for print science serials. While the prediction estimated a statewide cost over ten million dollars, the total actually is over twenty million dollars. This may be a low estimate because it does not include any second (or third!) copies held by the 75 libraries in the study. These data remind us that even in these electronic-centric times there are a number of reasons for libraries to continue to subscribe to print science journals as demonstrated by this large investment in current print subscriptions. Reasons include archiving responsibilities, a commitment to maintaining unique subscriptions only available in print, and even cost effectiveness. Some publisher contracts and license agree- ments require that libraries maintain a set level of subscriptions in print to secure lower pricing and online access.

Table 4 also clearly shows the dearth of pricing information available for nearly half of all titles in the study. Even after a graduate assistant conducted exhaustive title-by-title searching beyond Ulrich's including FirstSearch, publisher sites, and Google, no prices could be found for 7,029 titles. Because libraries are cost-conscious (very aware of what they are paying for a journal) and many of these titles were determined to be gifts or exchange materials, it is likely that there are no purchasing costs to libraries associated with these titles. Therefore, these journals (those with no price information) were not expected to have a dramatic impact on data analysis when price or cost was a factor.

Table 5 addresses two hypotheses, one that states that disciplines with the highest percentage of online journal availability will be chemistry and physics and that the most expensive journals by call number will be found in LC class QD (Chemistry). As seen in table 5, Library of Congress classification QR (Microbiology) has the highest percentage of journals available electronically, not chemistry or physics as was predicted. In fact, while chemistry has many more journals by classification than microbiology, its electronic availability for those journals (67.8\%) is well below Microbiology's 82 percent. However, chemistry does win the price war,

\begin{tabular}{|l|r|r|r|r|r|}
\hline \multicolumn{7}{|c|}{ TABLE 4 } \\
\hline The Number and Cost of Current Print Science Serials in Illinois Grouped \\
by Broad Price Range
\end{tabular}




\begin{tabular}{|c|c|c|c|c|c|c|}
\hline \multicolumn{7}{|c|}{$\begin{array}{c}\text { TABLE } 5 \\
\text { Current Print Science Journal Holdings by Le Classification Showing } \\
\text { Percentage of Electronic Access by Class and Total Expenditures by Class }\end{array}$} \\
\hline \multirow[t]{2}{*}{ LC Classification } & \multirow{2}{*}{$\begin{array}{c}\text { \# of } \\
\text { Copies }\end{array}$} & \multirow{2}{*}{$\begin{array}{l}\text { \# of } \\
\text { Titles }\end{array}$} & \multirow{2}{*}{$\begin{array}{c}\text { Ratio } \\
\text { Copies } \\
\text { Per Title }\end{array}$} & \multirow[t]{2}{*}{ E-Access } & \multirow{2}{*}{$\begin{array}{c}\% \\
\text { E-Access }\end{array}$} & \multirow[t]{2}{*}{ Total Price } \\
\hline & & & & & & \\
\hline BF-Psychology & 1,682 & 277 & 6.07 & 199 & $71.80 \%$ & $\$ 676,283.26$ \\
\hline HA-Statistics & 21 & 10 & 2.1 & 7 & $70.00 \%$ & $\$ 7,312.67$ \\
\hline HM-Anthropology & 312 & 94 & 3.32 & 58 & $61.70 \%$ & $\$ 98,025.07$ \\
\hline QA-Mathematics & 3,061 & 887 & 3.45 & 548 & $61.80 \%$ & $\$ 1,905,125.14$ \\
\hline QB-Astronomy & 197 & 51 & 3.86 & 35 & $68.60 \%$ & $\$ 115,421.75$ \\
\hline QC-Physics & 1,330 & 463 & 2.87 & 325 & $70.20 \%$ & $\$ 1,928,959.74$ \\
\hline QD-Chemistry & 1,514 & 367 & 4.13 & 249 & $67.80 \%$ & $\$ 3,335,993.86$ \\
\hline QE-Geology & 1,328 & 620 & 2.14 & 247 & $39.80 \%$ & $\$ 860,690.67$ \\
\hline Q-General Science & 1,301 & 367 & 3.54 & 179 & $48.80 \%$ & $\$ 693,891.61$ \\
\hline $\begin{array}{l}\mathrm{QH}-\text { Natural History } \\
\text { and Biology }\end{array}$ & 2,135 & 564 & 3.79 & 363 & $64.40 \%$ & $\$ 2,559,740.06$ \\
\hline QK-Botany & 643 & 247 & 2.6 & 119 & $48.20 \%$ & $\$ 370,517.31$ \\
\hline QL-Zoology & 797 & 306 & 2.6 & 132 & $43.10 \%$ & $\$ 346,532.93$ \\
\hline QP-Physiology & 1,442 & 400 & 3.61 & 322 & $80.50 \%$ & $\$ 2,019,489.28$ \\
\hline QR-Microbiology & 329 & 100 & 3.29 & 82 & $82.00 \%$ & $\$ 304,180.38$ \\
\hline $\mathrm{R}$-Medical & 5,506 & 1,581 & 3.48 & 1,117 & $70.70 \%$ & $\$ 2,891,513.90$ \\
\hline S-Agriculture & 1,374 & 614 & 2.24 & 268 & $43.60 \%$ & $\$ 353,696.70$ \\
\hline TA-TK-Engineering & 1,885 & 763 & 2.47 & 513 & $67.30 \%$ & $\$ 1,786,325.69$ \\
\hline $\begin{array}{l}\text { TL-Motor Vehicles, } \\
\text { Aeronautics }\end{array}$ & 230 & 74 & 3.11 & 44 & $59.50 \%$ & $\$ 57,127.86$ \\
\hline $\begin{array}{l}\text { TP-Chemical } \\
\text { Technology }\end{array}$ & 419 & 160 & 2.62 & 109 & $68.10 \%$ & $\$ 373,085.55$ \\
\hline TR-Photography & 133 & 27 & 4.93 & 15 & $55.60 \%$ & $\$ 7,432.80$ \\
\hline TS-Manufactures & 215 & 80 & 2.69 & 43 & $53.80 \%$ & $\$ 41,101.11$ \\
\hline T-Technology & 370 & 108 & 3.43 & 77 & $71.30 \%$ & $\$ 137,793.94$ \\
\hline TX-Home Economics & 228 & 68 & 3.35 & 46 & $67.60 \%$ & $\$ 49,260.48$ \\
\hline $\begin{array}{l}\text { Miscellaneous Classifi- } \\
\text { cations (including A, G, } \\
\mathrm{H}, \mathrm{L}, \mathrm{U}, \mathrm{V} \text {, and Z) }\end{array}$ & 429 & 127 & 3.38 & 91 & $71.20 \%$ & $\$ 76,392.89$ \\
\hline $\begin{array}{l}\text { No Classification Info } \\
\text { from Ulrichs }\end{array}$ & 104 & 59 & 1.76 & 34 & $57.60 \%$ & $\$ 50,050.35$ \\
\hline $\begin{array}{l}\text { No Price information } \\
\text { /Ulrichs or any source }\end{array}$ & 4,550 & 2,000 & 2.27 & 1,322 & $66.10 \%$ & $\$ 0.00$ \\
\hline No match in Ulrichs & 4,397 & 3,684 & 1.18 & N/A & N/A & N/A \\
\hline TOTAL & 35,932 & 14,098 & 2.55 & 6544 & $62.83 \%$ & $\$ 21,045,945.00$ \\
\hline
\end{tabular}




\begin{tabular}{|l|c|}
\hline \multicolumn{2}{|c|}{ TABLE 6 } \\
\multicolumn{2}{|c|}{$\begin{array}{l}\text { Data Showing Online Accessibility } \\
\text { of Nongift (Paid) Print Science } \\
\text { Serials that are Held in Illinois }\end{array}$} \\
\hline \hline $\begin{array}{l}\text { Total number of titles with } \\
\text { pricing information }\end{array}$ & 7,069 \\
\hline $\begin{array}{l}\text { Total number available } \\
\text { online with cost information }\end{array}$ & 5,222 \\
\hline $\begin{array}{l}\text { Percentage paid and } \\
\text { available online }\end{array}$ & $73.8 \%$ \\
\hline
\end{tabular}

with total expenditures for chemistry print serials in Illinois well over 2.7 million dollars per year and the average cost of a chemistry journal at $\$ 1,816.89$. These data show that chemistry is both the highest priced group of journals by class and the highest average cost, supporting this hypothesis. Table 5 also shows a whopping $\$ 21,045,945$ in expenditures for science serials among this group of libraries, underscoring the significant investment that is made for students and faculty throughout the state.

The final hypothesis predicted that over 80 percent of currently received nongift print science serial titles will be available online. Table 6 shows that this hypothesis is in the right ballpark, but falls slightly short of a direct hit. Nearly 74 percent of nongift (or paid) print serial subscriptions are available online. This is a good percentage, but by reviewing the data from table 5, which show online percentages by LC class, it is clear that a number of science disciplines still need to make inroads in online accessibility.

\section{Conclusions}

The data raise a number of questions concerning Illinois' current print science serial collection. Illinois is a state with a rich history of cooperative collection development; these findings indicate that serial subscriptions represent a unique opportunity to mine the relationships that Illinois libraries have built up over the years, and focus energies on retooling both holdings and subscriptions. The data point to the incredible stewardship responsibility that exists in Illinois and in every state or consortium and poses the urgent question of how best to protect the 73 percent of our science serial titles that are at risk. It also asks us to wonder, "What can we do better together than separately?"

This study provides a clear picture of how Illinois' science serial dollars are being spent. This statewide resource now has the potential to be utilized differently with these data at hand and the possibilities for managing a statewide collection. By pointing out what is actually being currently bought, bound, and shelved, by how many libraries and where, we can better decide if these decisions are right for today, or if they are just being carried over from generation to generation.

Data from this study can help to address last-copy or next-to-last-copy issues and to begin a discussion about moving to shared, consortium, or statewide electronic access. A clear need exists for shared archiving discussions and decisions to be made within Illinois and perhaps nationwide. In addition, materials with no pricing information comprise nearly 50 percent of current print science serial subscriptions in Illinois, most of which are not found in Ulrich's serials database and many of which have no ISSN and limited accessibility. This is a large percentage of titles for which more discussion is needed concerning the value and cost of keeping materials that are not well accessible. This study also points very clearly to the importance of up-to-date, accurate cataloging records and it emphasizes the stewardship and responsibility of ownership in a world that grows smaller and more interdependent each day.

Discussions for reducing the number of print copies of widely held titles and moving to shared online access could begin with those subject areas with the most titles available online (microbiology, physiology), or could focus on the most widely owned print titles, such as Science, Scientific American, and Consumer Reports, 
that are held by over 50 academic libraries in Illinois. Table 7 shows the most widely held print science serial subscriptions in the state, representing an excellent start-

\begin{tabular}{|c|c|c|c|c|}
\hline \multicolumn{5}{|c|}{$\begin{array}{c}\text { TABLE } 7 \\
\text { The Top } 28 \text { Most Widely Owned Print Science Subscriptions in Illinois } \\
\text { During the Study Period (Spring 2005) }\end{array}$} \\
\hline Title & $\begin{array}{c}\text { \# of } \\
\text { Libraries }\end{array}$ & $\begin{array}{c}\text { List } \\
\text { Price }\end{array}$ & $\begin{array}{c}\text { Total Price } \\
\text { all Libraries }\end{array}$ & E-Access \\
\hline Science & 58 & $\$ 425.00$ & $\$ 24,650.00$ & Yes \\
\hline Consumer Reports & 54 & $\$ 26.00$ & $\$ 1,404.00$ & Yes \\
\hline Scientific American & 53 & $\$ 24.97$ & $\$ 1,323.41$ & Yes \\
\hline Daedalus & 48 & $\$ 90.00$ & $\$ 4,320.00$ & Yes \\
\hline $\begin{array}{l}\text { Science News: the weekly newsmagazine } \\
\text { of science }\end{array}$ & 48 & $\$ 54.50$ & $\$ 2,616.00$ & Yes \\
\hline New England Journal of Medicine & 47 & $\$ 209.00$ & $\$ 9,823.00$ & Yes \\
\hline Natural History & 44 & $\$ 55.00$ & $\$ 2,420.00$ & Yes \\
\hline $\begin{array}{l}\text { Nature: international weekly journal of } \\
\text { science }\end{array}$ & 42 & $\$ 1,526.00$ & $\$ 64,092.00$ & Yes \\
\hline Psychology Today & 41 & $\$ 15.97$ & $\$ 654.77$ & Yes \\
\hline Physicians' Desk Reference & 40 & $\$ 82.95$ & $\$ 3,318.00$ & Yes \\
\hline $\begin{array}{l}\text { J A M A: The Journal of the American } \\
\text { Medical Association }\end{array}$ & 39 & $\$ 405.00$ & $\$ 15,795.00$ & Yes \\
\hline Journal of Chemical Education & 39 & $\$ 155.00$ & $\$ 6,045.00$ & Yes \\
\hline Discover: the world of science & 38 & $\$ 29.95$ & $\$ 1,138.10$ & Yes \\
\hline Mathematics Teacher & 37 & $\$ 99.00$ & $\$ 3,663.00$ & Yes \\
\hline $\begin{array}{l}\text { New Scientist: the global science and } \\
\text { technology weekly }\end{array}$ & 36 & $\$ 140.00$ & $\$ 5,040.00$ & Yes \\
\hline Annual Review of Psychology & 35 & $\$ 169.00$ & $\$ 5,915.00$ & Yes \\
\hline American Journal of Nursing & 34 & $\$ 149.00$ & $\$ 5,066.00$ & Yes \\
\hline $\begin{array}{l}\text { Environment: where science and policy } \\
\text { meet }\end{array}$ & 34 & $\$ 109.00$ & $\$ 3,706.00$ & Yes \\
\hline $\begin{array}{l}\text { Nursing (Year): the voice and vision of } \\
\text { nursing }\end{array}$ & 34 & $\$ 99.00$ & $\$ 3,366.00$ & Yes \\
\hline Teaching Children Mathematics & 34 & $\$ 99.00$ & $\$ 3,366.00$ & Yes \\
\hline American Psychologist & 33 & $\$ 562.00$ & $\$ 18,546.00$ & Yes \\
\hline Nursing Research & 33 & $\$ 231.95$ & $\$ 7,654.35$ & Yes \\
\hline Physics Today & 32 & $\$ 295.00$ & $\$ 9,440.00$ & Yes \\
\hline Annual Review of Biochemistry & 32 & $\$ 203.00$ & $\$ 6,496.00$ & Yes \\
\hline Annual Review of Physiology & 32 & $\$ 189.00$ & $\$ 6,048.00$ & Yes \\
\hline Annual Review of Genetics & 32 & $\$ 183.00$ & $\$ 5,856.00$ & Yes \\
\hline Hastings Center Report & 32 & $\$ 100.00$ & $\$ 3,200.00$ & Yes \\
\hline American Biology Teacher & 32 & $\$ 90.00$ & $\$ 2,880.00$ & Yes \\
\hline $\begin{array}{l}\text { Statewide total for the most widely } \\
\text { purchased } 28 \text { titles }\end{array}$ & & & $\$ 227,841.63$ & \\
\hline
\end{tabular}


ing point for statewide electronic access negotiated by a consortium representing all Illinois academic libraries.

Another way to begin is by identifying publishers with widely-owned current serial titles within the state and negotiating a single statewide current print subscription and online accessibility together, consortially, for the state. With a large database containing many fields, nearly any angle of this collection can be scrutinized and analyzed.

The authors believe that the answer to the question posed above, "What can we do better together than separately?" is to use the data and make decisions that increase electronic access through consortia purchases while reducing print copies (except those needed for archival purposes). To discuss this opinion, a statewide meeting of collection development librarians was held June 5, 2006. This meeting was sponsored by CARLI and featured guest speaker Paul Metz (from VIVA, the Virtual Library of Virginia). The daylong session presented research data from the Metz and Gasser study as well as this study and provided an overview of potential paths to take. At the end of the day, CARLI Executive Director Susan Singleton called for the creation of the "Statewide Serials Collection Task Force." This group's charge is to "investigate various collaborative options related to print and electronic serials collections across the state. Among other ideas, these options may include mechanisms for last subscription retention, last copy retention and electronic archiving." The road will be a long one, but Illinois has begun to move ahead in collaborating to create a statewide serial collection that not only preserves and protects our rich resources but extends access to this collection at the broadest level for the good of all citizens.

\section{Future Research}

This study suggests further inquiry in a number of areas that look to both the breadth and depth of information about serial subscriptions. Of primary interest is the potential for providing electronic access to high-cost, high-overlap journals and how negotiations for specific titles might best be advantageous to libraries. While reporting on specific negotiated terms is often not possible, it is still reasonable to follow the effects of moving from multiple print copies to a single statewide digital subscription and to understand the similarities and differences with other statewide agreements.

The authors have already been approached about continuing this study to other subject areas. In addition, a deeper understanding of interlibrary lending and access issues will help not only libraries but also publishers to appreciate the nuances of how more extensive licenses affect business models and budgets.

Libraries have always known that we are stronger collectively than individually. Economics and technology have converged to allow us to continue to move strongly ahead in our cooperative agreements, and a better understanding of journal overlap and use of digital subscriptions are the natural next steps in our evolution.

\section{Notes}

1. William Gray Potter, "Collection Overlap in the LCS \{Library computer system\} network in Illinois," Library Quarterly 56 (Apr. 1986): 119-41.

2. Mary Munroe, Susan Braxton, Carol Covey, et al., "A statewide collection map results from the statewide assessment of monograph and electronic resources in Illinois," Illinois Cooperative Collection Management Program. Available online at www.niulib.niu.edu/collectionmap/. [Accessed 5 May 2006].

3. Michael A. Norman and Chiat Chew Naun, "Ulrich's Serials Analysis System," Issues in Science E Technology Librarianship 38 (Summer 2003). Available online at www.istl.org/03-summer/databases.html. [Accessed 5 May 2006]. 
4. Robert B. Downs, Union Catalogs in the United States (Chicago: ALA, 1942).

5. Lisa Aren Strubbe, "Characteristics of Serials Duplication within an Academic Research Library," Library E Information Science Research 11 (Apr. 1989): 91-108.

6. Richard N. German, Tony Kidd, and Gordon E. C. Pratt, "Serials overlap in the higher education institution libraries in Glasgow," New Review of Academic Librarianship 3 (1997): 115-38.

7. A. N. Zainab, S. L. Ng, "Availability, Overlap and Cost of Quality Journal Subscriptions in Computer Science," LIBRES 14 (Mar. 2004): 1. Available online at http://libres.curtin.edu.au/ libres14n1/. [Accessed 5 May 2006].

8. Paul Metz and Sharon Gasser, "Analyzing Current Serials in Virginia: An Application of the Ulrich's Serials Analysis System," portal: Libraries and the Academy 6: 5-21. Available online at http://muse.jhu.edu/journals/portal_libraries_and_the_academy/v006/6.1metz.pdf. [Accessed 23 May 2006].

9. Brian E.C. Schottlaender, “Collection Management Strategies in a Digital Environment. Available online at www.ucop.edu/cmi/finalreport/index.html. [Accessed 8 September 2006].

10. Phillip M. Davis, "Patterns in Electronic Journal Usage: Challenging the Composition of Geographic Consortia," College E Research Libraries 63 (Nov. 2002): 484-497.

11. Thomas J. Sanville, "Use of Electronic Journals in OhioLINK's Electronic Journal Center," 67th IFLA Council and General Conference, August 16-25, 2001. Available online at www.ifla. org/IV/ifla67/papers/118-141e.pdf\#search=\%22thomas\%20sanville $\% 22$ [Accessed 8 September 2006].

12. CONSER's definition of a serial is available online at www.itsmarc.com/crs/manl1724.htm. [Accessed 22 May 2006].

13. Metz and Gasser, "Analyzing Current Serials," 8-10.

\section{Elegant Solutions for Preservation}

Call for a complete catalog

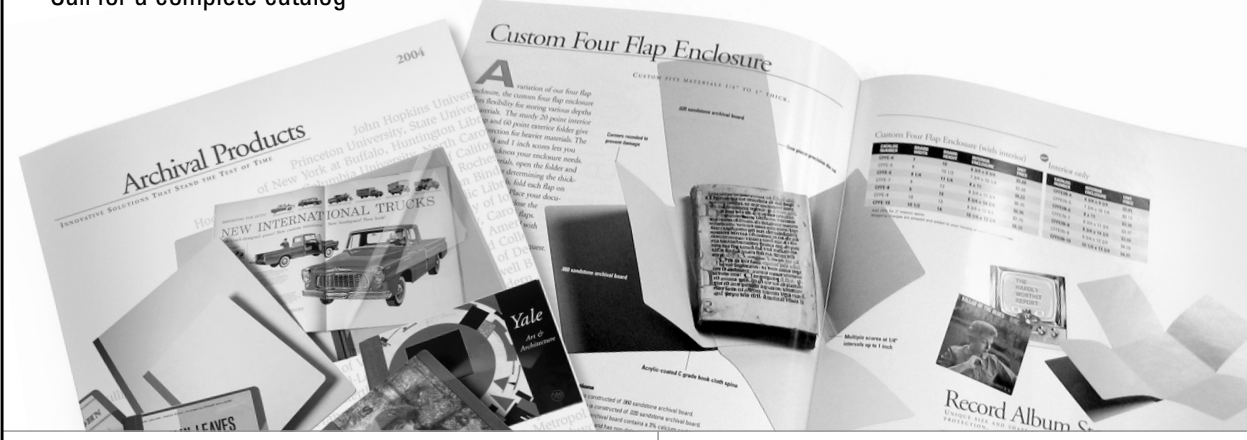

Pamphlet Binders Music Binders Archival Folders Manuscript Folders Hinge Board Covers Academy Folders Newspaper/Map Folders Polypropylene Sheet \& Photo Protectors

Conservation \& Preservation Tapes
Bound Four Flap Enclosures Archival Binders Archival Boards Adhesives Bookkeeper Century Boxes Record Album Enclosures Conservation Cloths
ARCHIVAL PRODUCTS

P.O. Box 1413 | Des Moines, Iowa 50305-1413 $800.526 .5640 \mid$ Fax 888.220.2397 custserv@archival.com | www.archival.com 


\begin{tabular}{|c|c|}
\hline \multicolumn{2}{|c|}{$\begin{array}{c}\text { APPENDIX A } \\
75 \text { Libraries Participating in Study }\end{array}$} \\
\hline Augustana College & MacMurray College \\
\hline Aurora University & McHenry County College \\
\hline Benedictine University & McKendree College \\
\hline Bradley University & Millikin University \\
\hline Catholic Theological Union & Monmouth College \\
\hline Chicago State University & Murphy College \\
\hline Columbia College & National-Louis University \\
\hline Concordia University & Newberry Library \\
\hline Depaul University & North Central College \\
\hline Dominican University & Northeastern Illinois University \\
\hline DuPage College & Northern Baptist Theological Seminary \\
\hline Eastern Illinois University & Northern Illinois University \\
\hline Elmhurst College & Northwestern University \\
\hline Eureka College & Oakton Community College \\
\hline Frontier Community College & Olivet Nazarene University \\
\hline Governors State University & Olney Central College \\
\hline Greenville College & Parkland Community College \\
\hline Heartland Community College & Principia College \\
\hline Illinois Central College & Quincy University \\
\hline Illinois College & Rend Lake College \\
\hline Illinois Institute of Technology & Robert Morris College \\
\hline Illinois Math and Science Academy & Saint Xavier University \\
\hline Illinois State University & Sauk Valley Community College \\
\hline Illinois Valley Community College & School of the Arts Institute \\
\hline Illinois Wesleyan University & SIU Carbondale Medical Library \\
\hline John Wood Community College & Southeastern Illinois College \\
\hline Joliet Junior College & Southern Illinois University at Carbondale \\
\hline Judson College & Southern Illinois University at Edwardsville \\
\hline Kankakee Community College & Trinity Christian College \\
\hline Kendall College & Triton College \\
\hline Kishwaukee College & University of Chicago \\
\hline Lake Forest College & University of Illinois at Chicago \\
\hline Lewis and Clark Community College & University of Illinois at Springfield \\
\hline Lewis University & University of Illinois at Urbana-Champaign \\
\hline Lincoln Land Community College & University of St. Francis \\
\hline Logan College & Western Illinois University \\
\hline Loyola University & Wheaton College \\
\hline & William Rainey Harper College \\
\hline
\end{tabular}

